\title{
Applicability of auriculotherapy in reducing stress and as a coping strategy in nursing professionals
}

\author{
Leonice Fumiko Sato Kurebayashi ${ }^{1}$ \\ Juliana Rizzo Gnatta ${ }^{2}$ \\ Talita Pavarini Borges ${ }^{2}$ \\ Maria Júlia Paes da Silva ${ }^{3}$
}

\begin{abstract}
Aims: randomized clinical trial aimed at evaluating the auriculotherapy in reducing stress levels in 75 nursing professionals and analyze the coping domains that have changed after treatment. Methodology: volunteers were divided into 3 groups (Control, Needles and Seeds) and received eight sessions at Shenmen, Kidney and Brainstem points. The Control Group didn't receive any intervention. Results: ANOVA test showed statistical differences in stress levels for Needle/Control Groups in the third and fourth assessments, according to Stress Symptoms List when compared the three groups in four assessments. For the Inventory of Folkman/Lazarus, a significant difference was obtained for Spacing domain between needle/control. In analysis within the same group, differences were found for Confrontation in fourth assessment between Needle/Control Groups and for Social Support in the third one between Seeds/Control Groups. Conclusion: The auriculotherapy decreased stress levels, changed Coping domains after treatment, suggesting that both Auriculotherapy with needles and seeds can produce positive impact to improve strategy Coping in the nursing team. However, more studies are needed to conceive the extent of the technique.
\end{abstract}

Descriptors: Auriculotherapy; Stress; Coping; Nursing.

\footnotetext{
${ }^{1}$ Doctoral student, Escola de Enfermagem, Universidade de São Paulo, Brazil.

2 Master's students, Escola de Enfermagem, Universidade de São Paulo, Brazil.

3 PhD, Full Professor, Escola de Enfermagem, Universidade de São Paulo, Brazil.
}

Corresponding Author:

Leonice Fumiko Sato Kurebayashi

Universidade de São Paulo. Escola de Enfermagem

Av. Dr. Enéas de Carvalho Aguiar, 419

Bairro: Cerqueira César

CEP: 05403-000, São Paulo, SP, Brasil

E-mail: fumie_ibez@yahoo.com.br 


\section{Aplicabilidade da auriculoterapia para reduzir estresse e como estratégia de coping em profissionais de enfermagem}

Objetivos: trata-se de ensaio clínico randomizado com o objetivo de avaliar a auriculoterapia, para diminuição de níveis de estresse, em 75 profissionais de enfermagem de um hospital e analisar os principais domínios de coping que se modificaram após o tratamento. Metodologia: os sujeitos foram divididos em grupos (controle, agulhas, sementes), receberam 8 sessões nos pontos Shenmen, rim e tronco cerebral. O grupo controle não recebeu nenhuma intervenção. Resultados: constataram-se diferenças significativas pela ANOVA, para níveis de estresse entre o grupo agulha/controle na terceira e quarta avaliações, segundo escores de estresse da Lista de Sintoma de Stress de Vasconcelos. Para o Inventário de Folkman e Lazarus, obtevese diferença estatística para o domínio afastamento entre os grupos agulha/controle, após tratamento; e, na análise dentro do mesmo grupo, obtiveram-se diferenças significativas para o domínio confronto, na quarta avaliação entre grupos agulha/controle e para suporte social, na terceira avaliação para os grupos agulha/semente. Conclusões: a auriculoterapia com agulhas diminuiu os níveis de estresse significativamente e houve diminuição da utilização dos domínios afastamento, confronto e suporte social para os grupos de intervenção, após o tratamento, sugerindo que a auriculoterapia tanto com agulhas quanto com sementes pode produzir impacto positivo para melhorar a estratégia de coping na equipe de enfermagem. Mais estudos, porém, fazem-se necessários para que se possa conhecer o alcance da técnica.

Descritores: Auriculoterapia; Estresse; Coping; Enfermagem.

\section{Aplicabilidad de la auriculoterapia para reducir estrés y como estrategia de coping en profesionales de enfermería}

Objetivos: Ensayo clínico hecho aleatorio objetivó evaluar la auriculoterapia para disminución de niveles de estrés en 75 profesionales de Enfermería de un hospital y analizar los principales dominios de Coping que se modificaron después del tratamiento. Metodología: los sujetos fueron divididos en grupos (Control, Agujas, Semillas), recibieron 8 sesiones en los puntos Shenmen, Riñón y Tronco Cerebral. El Grupo Control no recibió ninguna intervención. Resultados: se constataron diferencias significativas por la ANOVA para niveles de estrés entre el Grupo Aguja/Controle en la tercera y cuarta evaluaciones, según scores de estrés de la Lista de Síntoma de Estrés de Vasconcelos. Para el Inventario de Folkman y Lazarus, se logró diferencia estadística para el dominio Alejamiento entre los Grupos Aguja/Controle después del tratamiento; y en el análisis dentro del mismo grupo, se lograron diferencias significativas para el dominio Confrontación en la cuarta evaluación entre Grupos Aguja/Controle y para Soporte Social, en la tercera evaluación para los Grupos Aguja/Semillas. Conclusiones: la auriculoterapia con agujas apocó los niveles de estrés significativamente y hubo disminución de la utilización de los dominios Alejamiento, Confrontación y Soporte Social para los grupos de intervención después del tratamiento, sugiriendo que la auriculoterapia tanto con agujas cuanto con semillas puede producir un impacto positivo para mejorar estrategia de Coping en el equipo de Enfermería. Más estudios, sin embargo, se hacen necesarios para que se pueda conocer el alcance de la técnica.

Descriptores: Auriculoterapia; Estrés; Coping; Enfermería.

\section{Introduction}

The physical, mental and psychic well-being can impact significantly in the results and productivity of the worker, especially those that deal with health, and work in a high stress environment, such as a hospital ${ }^{(1)}$.
There is consensus that psychological and social factors can cause problems in the health of individuals and that the Coping strategies in situations of stress may be determinants of the mental, physical and social health ${ }^{(2)}$ 
The structural work conditions of health professionals, often poorly paid, little encouraged and subject to a considerable overload of activities, hinder the possibility of performing humanized care, since the humanizing process begins with the humanization of the production of this care(3).

It is noteworthy, therefore, that to care for professionals who provide healthcare services can be a key strategy, since good results in the care mainly depend on healthy work teams, especially considering that nurses deal with conflicts and errors in the vertical and horizontal relationships between professionals, family members and patients on a daily basis.

Attention has focused on Coping with stress and instruments have been developed to evaluate how people cope with difficulties or stressful circumstances in their lives. In this context Coping emerges as a more elaborate, adaptive, flexible and conscious response to a given stressor element. The Coping concept differs from concept of the defense mechanism in stress situations, because the responses obtained in this mechanism are classified as rigid, inadequate in relation to the external reality and may originate from past issues and elements of the unconscious( ${ }^{(4)}$. Conversely, a Coping response is an intentional, physical or mental action, initiated in response to a perceived stressor, directed toward the external circumstances or internal states, with this response guided by attempting to reduce the stress ${ }^{(5)}$.

Eastern cultures have historically developed strategies for coping with stress from bodily practices, exercises, movements, dances and massage, aiming to preserve and restore health, to flexibility and strengthening of the body and mind(6). The benefit of such practices in the maintenance of quality of life was the main motivation to perform this study. There are numerous types of alternative therapies and bodily practices, some of them ancient, which seek to cure diseases and increase well-being, as in acupuncture, herbal medicine and massage, and to attain spiritual balance and harmony, as is the case for tai chi chuan, yoga and meditation ${ }^{(7)}$.

Chinese auriculotherapy is a Traditional Chinese Medicine practice and is a method that uses specific points on the ear to treat various disorders of the body ${ }^{(8)}$. Auriculotherapy is indicated for the treatment of many disorders: pain, inflammation, endocrine metabolic and urogenital system problems, disorders of a functional nature, chronic and infectious-contagious diseases, etc. It is indicated in cases where the patient has a need for immediate pain relief, or when they have stinging, acute and chronic pains, mental disorders, such as anxiety and depression, distress, lack of concentration, dizziness, stuttering, disorders of the autonomic system, or intoxication from drug, tobacco and medication use. Conventionally, auricular acupuncture employs semipermanent or systemic needles as instruments to stimulate the points ${ }^{(9)}$. Seeds or magnets can also be utilized to perform the stimulation ${ }^{(10)}$.

The mechanism of action of auriculotherapy has been discussed and it is speculated that the technique works because groups of pluripotent cells contain information about the whole organism and create regional centers of organization that represent different parts of the body. When the reflex points in the ear are stimulated the relief of symptoms in distant parts of the body can be achieved ${ }^{(9)}$. Stimulating points can also activate small myelinated nerve fibers that send impulses to the spinal column, brain, pituitary and hypothalamus, causing the release of endorphins into the blood in the treatment of pain ${ }^{(11)}$.

Regarding the ethical-legal aspects of the practice of acupuncture, the Federal Nursing Council established in Resolution 197/97 that various complementary practices, among them acupuncture, are specialties of the nurse(12). Furthermore, from 2006, Regulation No. 971, of May $3^{\text {rd }}, 2006$, approved the National Policy on Integrative and Complementary Practices (PNPIC), which defined acupuncture as a multidisciplinary practice, i.e., as a specialty of all categories of higher level healthcare professionals, guaranteeing the practice of the acupuncturist nurse ${ }^{(13)}$.

From these previous reflections, it was questioned whether auriculotherapy would be useful for diminishing the stress levels of the Nursing team and whether it would have the therapeutic reach of, by itself, modifying the coping of stress, with significant changes in Coping domains according to the questionnaire of Folkman and Lazarus.

\section{Aims}

The aims of this study were to evaluate the efficacy of auriculotherapy with needles and seeds in reducing the stress levels of the nursing team employees of a hospital, and to identify and analyze differences between before and after the treatment in the Coping domains according to the questionnaire of Folkman and Lazarus.

\section{Materials and Method}

Study Type: This is a Randomized Controlled Clinical 
Trial with 3 groups: a control group (no intervention) and two intervention groups (auriculotherapy with needles and auriculotherapy with seeds).

Ethical and legal aspects: The research was conducted in a teaching hospital in São Paulo. The study followed Resolution 196/1996 of the National Health Council, regarding the involvement of human beings in the research. The research project was accepted by the Research Ethics Committee with registration No. 941/09-SISNEP CAAE: 0060.0.198.000-09. The participants of the Control Group were given the opportunity to, after study, be treated for the same period and for free with one of the auriculotherapy techniques used in the study.

Sample: To define the sample of participants the Inventory about the Stress State or Vasconcellos' List of Stress Symptoms - LSS was used ${ }^{(14)}$. This instrument was applied with all those who expressed interest in participating in the study (109), however, only those individuals who attained medium, high or very high scores were invited to participate; 75 of them managed to complete the study.

The allocation of the participants was performed through the distribution of opaque envelopes, containing a number and sealed. Numbers were then randomly generated and allocated to the three groups using the website www.randomizer.org. Of the 75 who completed the study, 22 subjects were in the Control Group, 27 in the Needle Group and 26 in the Seed Group. From the sample calculation, it could be affirmed that the sample had a test power of $80 \%$ for a significance level of $5 \%$, or confidence level of $95 \%$.

Inclusion criteria were: voluntary participation in the study with time available to commit to the sessions, achieving medium and high level scores in the LSS, not suffering from kidney stones with surgical indication and not being pregnant. Subjects were excluded for various reasons, explained in the fluctuation of subjects diagram (Figure 1). Due to "other reasons" those who did not attend the first session and some non-nursing professionals were excluded.

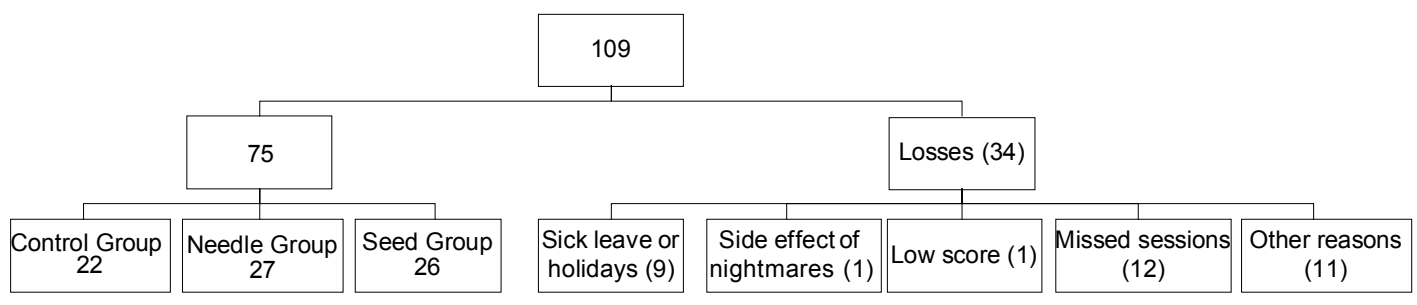

Figure 1 - Diagram of fluctuation of the research subjects. São Paulo, SP, Brazil, 2011

Data Collection: The List of Stress Symptom (LSS), a questionnaire with socio-demographic data and the Folkman and Lazarus' Ways of Coping questionnaire(15) were used to collect the data. This was carried out between January and July 2010 in a consulting room at the hospital. The instruments were applied by nurses, two with experience in auriculotherapy and four of them, prepared only for performing the study. In the LSS, with 60 items, the frequency with which the symptoms occur is indicated, from a scale of 4 response options: (0) never, (1) rarely, (2) often, and (3) always. The total score of this inventory can vary from 0 to 177 points, with scores representing the stress levels of: absente ( 0 to 11 points), low level (12 to 28 ), medium level (29 to 60 ), high level (61 to 120) and extremely high level (over 120 points). Regarding the Ways of Coping questionnaire, it contains 66 items, encompassing thoughts and actions that people use to deal with the internal or external demands of a stressful event. The questions are scored using a Likert type scale, where $0=$ not used; 1 = used somewhat; 2 = used quite a bit; 3 = used a great deal. The scale consists of 8 different "domains" suggested by the factorial analysis: confrontive coping, distancing, self-controlling, seeking social support, accepting responsibility, escape-avoidance, planful problemsolving and positive reappraisal.

The LSS and Ways of Coping questionnaire were applied before the treatment at the beginning of the study, after 4 sessions, after 8 sessions and 15 days after the termination. The intervention groups received 8 sessions ( 1 per week), lasting 5 to 10 minutes each, in the Shen Men, Kidney and Brainstem points. The Shen Men and Brainstem points have calming properties and the Kidney has an energy function ${ }^{(8)}$. For the auriculotherapy with semi-permanent needles, after proper localization of the reactive points, cleaning with cotton wool and $70 \%$ ethyl alcohol was performed on the pinna and the needles were applied and affixed with micropore tape. For the group of auriculotherapy with seeds, mustard seeds were used and the subjects were 
instructed to stimulate the seeds three times a day, for fifteen days, using moderate pressure. It was suggested that the needles be withdrawn 24 hours before the consultation or if there was discomfort, pruritus or signs of allergy.

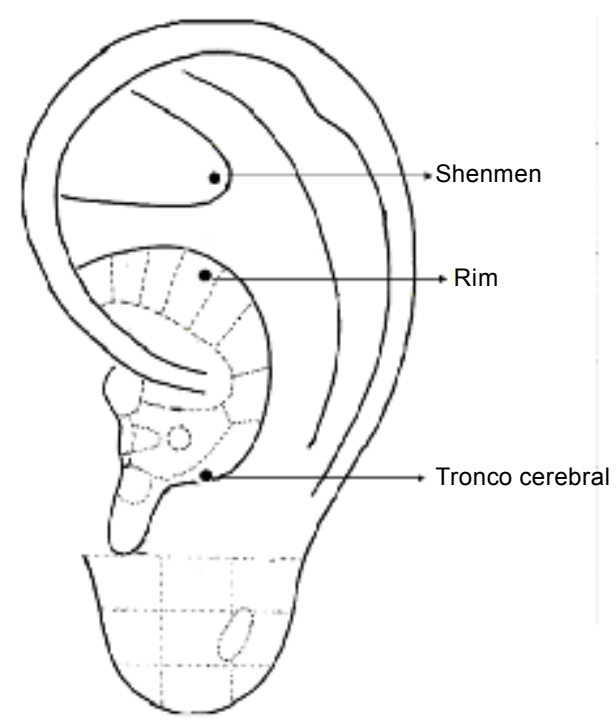

Figure 2 - Map of auricular points. São Paulo, SP, Brazil, 2011

Statistical analysis of data: For the statistical analysis, the following parametric tests were used, ANOVA for repeated measures, after Levene's test and the Kolmogorov-Smirnov test. The Bonferroni Post Hoc test was carried out for stress levels among the three groups at four moments in time. For the analysis of the domains of the Ways of Coping questionnaire, homogeneity was observed for the Mauchly's sphericity test and ANOVA with Tukey's Post Hoc test was performed. The MS Excel program (2007) was used for the tabulation of the data and the statistical program SPSS 17.0.

\section{Results}

Of the 75 professionals, 12 were auxiliary nurses, 49 were nursing technicians and 14 nurses; 44 of them, representing $58.7 \%$, presented scores related to medium levels of stress and $31(41.3 \%)$ presented scores related to high levels. The ages of the subjects ranged between 39 to 45 years and the employees were from various sectors of the Hospital. According to the results in Table 1, it can be observed from the significance level $(p<0.05)$, that there was homogeneity between the groups regarding age, length of employment and initial LSS. Regarding gender, there was a predominance of females (71), who corresponded to $94.6 \%$ of the sample, with homogeneous distribution between the groups of the few men (4) who participated in the study $(p=0.65)$.

In the descriptive analysis of the domains found in Folkman and Lazarus' Ways of Coping questionnaire the following scores were obtained at the first evaluation: Confrontive Coping domain (mean: 5.97), Distancing (mean: 5.81), Self-Controlling (mean: 7.72), Seeking Social Support (mean: 8.96), Accepting Responsibility (mean: 8.99), Escape-Avoidance (mean: 3.12) and Planful Problem Solving domain (mean: 6.24). The scores for all items corresponded to - this strategy was "used quite a bit", with the exception of the Positive Reappraisal domain (mean: 15.05), where a score was obtained corresponding to "used a great deal".

Concerning the stress levels (Table 1 ), statistically significant differences were verified in the ANOVA for repeated measures, when comparing the three groups, at 4 different moments (LSS1, LSS2, LSS3, LSS4). The significance level between the differences in the results according to the Bonferroni test was $p=0.020$ between LSS3 and LSS1 and $p=0.003$ when comparing LSS4 and LSS1. The Seed Group showed no statistically significant differences regarding stress levels, when comparisons were performed between the groups at the four times, although positive results were obtained when compared within the same group, over time, with a significance level of $p<0.05$.

Table 1 - Evolution of the means and standard deviation of the scores of the LSS according to groups. São Paulo, Brazil, 2011

\begin{tabular}{|c|c|c|c|c|}
\hline & LSS1 & LSS2 & LSS3 & LSS4 \\
\hline Control & $54.36(15.90)$ & 49.68(17.99) & $55.09(25.93)$ & $55.77(30.98)$ \\
\hline Needle & $66.82(18.56)^{*}$ & $54.69(27.10)^{\dagger}$ & $52.91(26.79)$ & $48.48(27.35)^{+}$ \\
\hline Seed & $63.27(26.05)^{\ddagger}$ & $54.00(25.64)$ & $52.77(26.94)$ & $53.36(32.72)$ \\
\hline
\end{tabular}

* $\mathrm{p}<0.05$ when compared to the other scores of the LSS in the Needle Group.

$+p<0.05$ in the comparison between LSS 2 and LSS 4 .

$\neq \mathrm{p}<0.05$ when compared to the other scores of the LSS in the Seed Group. 
Regarding the domains of Folkman and Lazarus' Ways of Coping questionnaire, the only domain that presented a statistically significant difference in the analysis between groups was Distancing, with $p=0.039$, as shown in Figure 3 below.

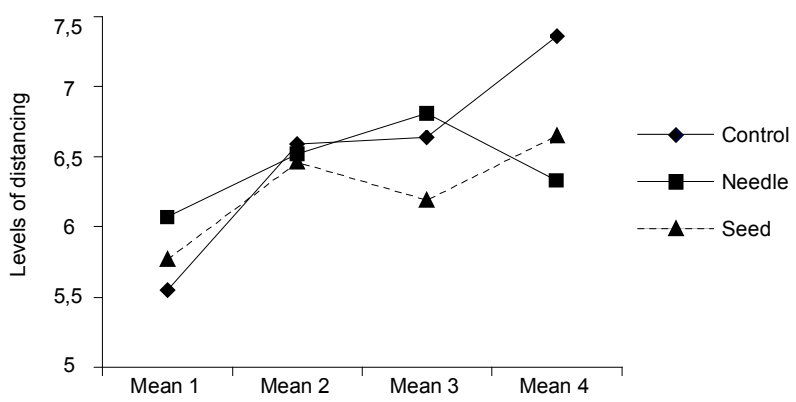

$p<0.05$ between Control and Needle Groups in the fourth evaluation.

Figure 3 - Evolution of the Means in the Distancing domain at the four evaluations. São Paulo, SP, Brazil, 2011

In the Distancing domain there was a change, from the initial mean obtained at the first evaluation (5.77) to the final mean at the fourth evaluation (6.65), which is to say that there was a change of level from "not used or used these strategies somewhat" to "used quite a bit". When an analysis of the domains within the same group was performed, a statistically significant difference was observed in the Confrontive Coping and Seeking Social Support domains, with a significance of $p=0.029$, for the Confrontive Coping domain between the first and fourth evaluation in the Needle Group and in the Seeking Social Support domain, between the first and third evaluation $(p=0.022)$ in the Seed Group.

In Table 2, the mean scores of the domains at the four moments and the main factors and scores involved.

Table 2 - Description of the differences between the four evaluation moments in the Distancing, Confrontive Coping and Seeking Social Support domains. São Paulo, SP, Brazil, 2011

\begin{tabular}{lcccc}
\hline & Mean 1 & Mean 2 & Mean 3 & Mean 4 \\
\hline Distacing & & & & \\
Control & $5.55^{*}$ & 6.59 & 6.64 & 7.36 \\
Needle & 6.07 & 6.52 & 6.81 & 6.33 \\
Seed & $5.77^{*}$ & 6.46 & 6.19 & 6.65 \\
Confrontive Coping & & & & \\
Control & 5.05 & 6.05 & 6.09 & 7.14 \\
Needle & 6.59 & 5.81 & 6.37 & 6.07 \\
Seed & 6.12 & 5.5 & 6.23 & 5.96 \\
Seeking Social & & & & \\
Support & & & & \\
Control & 8.77 & 9.73 & $11.32^{\dagger}$ & $10.77^{\dagger}$ \\
Needle & 8.81 & 8.81 & 8.81 & 8.67 \\
Seed & 9.27 & 8.96 & 8.73 & 9.23 \\
\hline
\end{tabular}

* This strategy was 'not used' or 'used somewhat'. + 'Used a great deal'. The others: 'Used quite a bit' www.eerp.usp.Br/rae

\section{Discussion}

There was a decrease in stress levels for the Needle Group from the third evaluation, confirming the efficacy of the auriculotherapy for the treatment of stress. For Traditional Chinese Medicine (TCM), by balancing energy aspects through the stimulation of points in the body or in microsystems, such as the ear, favorable conditions are provided for there to be a change in the social, emotional, physical, mental and spiritual behavior patterns of the individual(15). Auriculotherapy, as one of the techniques used in TCM, has been widely employed for the control of anxiety and psychological problems, as it promotes relaxation(16-17).

Although studies were found regarding the decrease in anxiety and stress from the use of auriculotherapy ${ }^{(18-19)}$, no studies were found on the applicability of this technique for Coping and dealing with stress.

In the present study, Positive Reappraisal was found to be the main Coping strategy domain, in which the score corresponded to "used a great deal", suggesting that the nursing staff of this hospital used emotionfocused Coping in their quotidian. Similar result was obtained in the study carried out on Coping strategies among Oncology nurses, whose highest scoring domain was also that of Positive Reappraisal(5).

Emotion-focused Coping is an attempt to regulate the emotional state, directed towards a somatic level and/or a level of emotions, usable in situations where there is no possibility of change, where problems may be structural and external to the personal action. Folkman and Lazarus proposed this Coping model, the situational approach of which divides Coping in two functional categories: Problem-focused and emotion-focused coping. Problem-focused Coping is an attempt to act on the situation, trying to modify it, and can be internally or externally directed. Generally such Coping tends to be used in situations previously evaluated as modifiable. Studies indicate that both strategies are used during practically all stressful episodes and that the use of one or other may vary in efficacy, depending on the different types of stressors involved(20).

There are two ways to approach Coping styles. The structural model that relates styles to personality traits, and the situational approach, which considers the strategies that refer to thoughts and actions taken in the course of a stressful event. The situational approach has been emphasized, since the way each individual faces stress can be determined by several factors, such as environmental ${ }^{(21)}$ and sociocultural aspects(22), age(23) and gender(24). 
The domains that presented statistically significant differences were Distancing, Confrontive Coping and Seeking Social Support. Distancing corresponds to a strategy that involves denying the feeling of fear or anxiety arising from a stressful situation. In this strategy, the individual tries to forget the truth, refusing to believe that the situation is actually happening(25). There was an increase in the scores in this domain in the Control Group, justifying the statistical differences found.

Conversely, the domains Confrontive Coping and Seeking Social Support can be considered problemfocused Coping strategies. In the Confrontive Coping domain strategies are found that include the view of defiance and attention to one aspect of the situation. In both the group that was treated with seeds as well as the one treated with needles there were decreases in these means and, conversely, increases in the means of the Control Group. The Seeking Social Support domain includes strategies that seek assistance to help resolve the problem. Some possibilities could be: to look for friends, relatives and to ask for advice, to talk with other specific people looking for data regarding the situation, to speak with someone who could do something concrete about the problem, to seek professional help and to accept the comprehension of the people(25). In this domain, there was a decrease in the means in the Seed Group, however, not sufficient to modify the score "used quite a bit". The Control Group, however, achieved the score "used a great deal" in the third and fourth evaluations.

The results suggested that external stressful situations occurred during the study period, justified by the significant increase in the scores of the Control Group in the domains Distancing, Confrontive Coping and Seeking Social Support, whereas in the intervention groups, the people made less use of these strategies. The main limitation of the study was that no survey of these stress factors was performed. Furthermore, not delineating the variables that presented uniformity regarding the problems experienced hindered further analysis of the effects of the auriculotherapy on the Coping strategies. Further studies are suggested in order to investigate how auriculotherapy can modify these strategies and patterns of behavior.

\section{Conclusions}

Of the 75 participants, $44(58.7 \%)$ presented medium level of stress and $31(41.3 \%)$ presented high levels. The main Coping domain found in the Nursing team according to Folkman and Lazarus' inventory was Positive Reappraisal. The auriculotherapy treatment was positive for decreased levels of stress in the Nursing team, with better results for semi-permanent needles than for seeds. There was a decrease in the use of the Distancing, Confrontive Coping and Seeking Social Support domains for the intervention groups after the treatment, suggesting that auriculotherapy, both with needles and seeds, can produce a positive impact to improve the Coping strategy in the Nursing team. Further studies, however, are necessary in order for the scope of the technique to be ascertained.

\section{References}

1. Batista KM, Bianchi ERF. Stress among emergency unit nurses. Rev. Latino-Am. Enfermagem. [periódico na Internet]. 2006 [acesso 3 jan 2012];14(4):534-9. Disponível em: http://www.scielo.br/pdf/rlae/v14n4/ v14n4a10.pdf

2. Guerrer FJL, Bianchi ERF. Characterization of Stress in Intensive Care Unit Nurses. Rev Esc Enferm USP. [periódico na Internet]. 2008 [acesso 3 jan 2012];42(2):355-62. Disponível em: http://www.scielo. $\mathrm{br} / \mathrm{pdf} /$ reeusp/v42n2/a19.pdf

3. Deslandes F. Analysis of the official speech about humanization of the hospital assistance. Ciência Saúde Coletiva. [periódico na Internet]. 2004 [acesso 3 jan 2012];9(1):7-14. Disponível em: http://redalyc. uaemex.mx/pdf/630/63013499002.pdf

4. Folkman S, Lazarus RS. An analysis of Coping in a middle-aged community sample. J Health Soc Beh.1980;25:229-44.

5. Rodrigues $A B$, Chaves EC. Stressing factors and coping strategies used by oncology nurses

Rev. Latino-Am. Enfermagem. [periódico na Internet]. 2008 [acesso 3 jan 2012];16(1):24-8. Disponível em: http://www.scielo.br/pdf/rlae/v16n1/pt_03.pdf

6. Secretaria Municipal de Saúde de São Paulo (BR). Caderno Temático em Medicina Tradicional Chinesa [internet]. 2002 [acesso 3 jan 2012]. Disponível em: http://ww2.prefeitura.sp.gov.br//arquivos/secretarias/ saude/areas_tematicas/0047/MTC_CadernoTematico. pdf

7. Souza EFAA, Luz MT. The socio-cultural bases of alternative therapeutic practices. Hist Cienc SaúdeManguinhos. 2009;16(2):393-405.

8. Giaponesi ANL, Leão ER. A auriculoterapia como intervenção para redução do estresse da equipe de 
enfermagem em terapia intensiva. Nursing (São Paulo). 2009;12(139):575-9.

9. Gori L, Firenzuoli F. Ear Acupuncture in European Traditional Medicine. Evid Based Complement Alternat Med. [periódico na Internet]. 2007 [acesso $13 \mathrm{dez}$ 2011];4(Suppl 1):13-6. Disponível em: http://www. ncbi.nlm.nih.gov/pmc/articles/PMC2206232/pdf/ nem106.pdf

10. Suen LKP, Thomas KSW, Leung AWN. Auricular therapy using magnetic pearls on sleep: a standardized protocol for the elderly with insomnia. Clin Acup Orient Med. 2002;3:39-50.

11. Hui KK, Liu J, Makris N, Gollub RL, Chen AJ, Moore CI, Kennedy DN, Rosen BR, Kwong KK: Acupuncture modulates the limbic system and subcortical gray structures of the human brain: Evidence from fMRI studies in normal subjects. Hum Brain Map. 2000;9:1325 .

12. Conselho Federal de Enfermagem (BR). Resolução COFEN 197. Estabelece e reconhece as Terapias Alternativas como especialidade e/ou qualificação do profissional de Enfermagem [Internet]. Brasil; 1997. [acesso $30 \mathrm{dez}$ 2011]. Disponível em: http:// www.portalcofen.gov.br/Site/2007/materias. asp?ArticleID $=7041 \&$ sectionID $=34$

13. Ministério da Saúde (BR). Portaria No 971 de 3 de maio de 2006. Aprova a Política Nacional de Práticas Integrativas e Complementares (PNPIC) no Sistema Único de Saúde. Diário Oficial da União. 2006;84:20-5. 14. Ferreira EAG, Vasconcellos EG, Marques AP. Assessment of pain and stress in fibromyalgia patients. Rev Bras Reumatol. 2002;42:104-10.

15. Bellotto N Junior, Martins LC, Akerman M. Impacto dos resultados no tratamento por acupuntura: conhecimento, perfil do usuário e implicações para promoção da saúde. Arq Med ABC. [periódico na Internet]. 2005 [acesso 30 dez 2011];30(2):83-6. Disponível em: http://site. fmabc.br/admin/files/revistas/30amabc083.pdf 16. Wang SM, Kain, ZN. Auricular acupuncture: a potential treatment for anxiety. Anesth Analg. 2001;92:548-53.

17.Wang SM, Peloquin C, Kain ZN. The use of auricular acupuncture to reduce preoperative anxiety. Anesth Analg. 2001;93:1178-80.

18. Kober A, Scheck T, Shubert B, Strasser H, Gustorff B, Bertalanffy $P$ et al. Auricular acupressure as a treatment for anxiety in prehospital transport settings. Am Soc Anesthesiol. 2003;98(6):1328-32.

19. Arai YCP, Ito A, Hibino $S$ et al. Auricular acupunctures are effective for the prevention of postoperative agitation in old patients. eCAM. 2009 Oct; 1-4.
20. Savóia MG, Santana PR, Mejias NP. Adaptação do inventário de estratégias de Coping de Folkman e Lazarus para o português. Psicologia USP. 1996;7(1/2):183-201. 21. Antoniazzi AS, Souza LK, Hutz CS. Coping em situações específicas, bem-estar subjetivo e auto-estima em adolescentes. Rev Interinst Psicol. 2010;2(1):34-42. 22. Chun CA, Moos RH, Cronkite RC. Culture: A Fundamental Context for the Stress and Coping Paradigm [monografia na Internet] [acesso 30 dez 2011]; Disponível em: http://www.mebsbooks.com/cover_note/ books/9/6/3/9780387262369/9780387262369-c1.pdf 23. Câmara SG, Carlotto MS. Coping e gênero em adolescentes. Psicol Estudo. (Maringá). 2007;12(1):8793.

24. Coelho JAPM, Albuquerque FJB, Martins CR, D'Albuquerque HB, Neves MTS. Coping em Jovens frente à expectativa de inserção ocupacional e indicadores de depressão. Psicol: Teor Pesq. 2008;24(4):527-34.

25. Antoniazzi AS, Dell'Aglio DD, Bandeira DR. O conceito de Coping: uma revisão teórica. Estud Psicol. 1998;3(2):273-94.
Received: Jan. $8^{\text {th }} 2012$ Accepted: Sept. 14th 2012 